\title{
Mechanical strain disrupts primary cilia structure and modulates hedgehog signalling in adult chondrocytes
}

\author{
CL Thompson ${ }^{1,2^{*}}$,JP Chapple ${ }^{2}$, MM Knight ${ }^{1}$ \\ From First International Cilia in Development and Disease Scientific Conference (2012) \\ London, UK. 16-18 May 2012
}

Chondrocytes are the unique cellular component of articular cartilage, the connective tissue covering the converging bone surfaces in joints. Chondrocytes within articular cartilage possess primary cilia although their function is unclear. In osteoarthritis hedgehog signalling, which takes place on the cilium, is aberrantly activated promoting cartilage degradation through the upregulation of ADAMTS5. The mechanisms for this, and the associated increase in cilia length and prevalence, are unknown. This study tests the hypothesis that alterations in mechanical loading influence cilia length and hedgehog signalling leading to increased ADAMTS-5 expression. Mature bovine articular chondrocytes were subjected to $5 \%, 10 \%$ or $20 \%$ cyclic tensile strain (CTS). CTS significantly reduced mean primary cilia length $(\mathrm{p}<0.05)$ in a dose-dependent manner such that cilia became progressively shorter with increasing strain magnitude. Indian Hedgehog gene expression was significantly increased by CTS at all strains $(p<0.05)$. Pathway activation (Patched1 gene expression), was observed at $5 \%$ and $10 \%$ strain but not $20 \%$ strain where the greatest reductions in cilia length occurred. Similarly, the mRNA levels of ADAMTS-5 were significantly increased by CTS at $5 \%$ and $10 \%$ strain $(\mathrm{p}<0.05)$ but not at $20 \%$ strain. These data suggest that mechanical loading activates hedgehog signalling in adult chondrocytes promoting cartilage degradation and highlights a link between primary cilia structure and function in cartilage disease.

\section{Author details}

${ }^{1}$ Queen Mary University of London, UK. ${ }^{2}$ Barts and the London School of Medicine and Dentistry, UK.

\footnotetext{
* Correspondence: c.l.thompson@gmul.ac.uk

${ }^{1}$ Queen Mary University of London, UK

Full list of author information is available at the end of the article
}

Published: 16 November 2012

doi:10.1186/2046-2530-1-S1-P53

Cite this article as: Thompson et al: Mechanical strain disrupts primary cilia structure and modulates hedgehog signalling in adult chondrocytes. Cilia 2012 1(Suppl 1):P53.
Submit your next manuscript to BioMed Central and take full advantage of:

- Convenient online submission

- Thorough peer review

- No space constraints or color figure charges

- Immediate publication on acceptance

- Inclusion in PubMed, CAS, Scopus and Google Scholar

- Research which is freely available for redistribution

\section{() Biomed Central}

